\title{
Fear and Flight from Responsibility
}

If in the plays examined so far, base desires lead to characters ignoring the voice of their consciences, in several plays fear provides the motivation for morally questionable actions. In three dramas, "Der Prozess", "Casa Speranza. Schauspiel in fünf Akten" and Der Flüchtling. Schauspiel in drei Akten, nach einem Entwurf von Georg Kaiser, such fear leads to flight from very real dangers. However, while escape may be the only means of survival, each play nevertheless insists on the moral duty to battle and confront evil, even when the temptation may be to think solely of one's own safety and concerns. In examining "Der Prozess", an immediate problem arises with two similar, but not identical, typescript versions of the play ${ }^{1}$. The main differences between the two are the locations and names of the characters: one is set in England and has figures with English names; the other is set in an unspecified place near a city, with characters with Germanic names. Aside from that the plots of both are virtually the same, except for minor differences in the third act, which in the shorter "German" version has been abridged ${ }^{2}$ with some inconsistencies being removed ${ }^{3}$. For this reason and because both Bortenschlager $^{4}$ and Murphy ${ }^{5}$, who had access to the unpublished works during Hochwälder's lifetime, refer only to the version which is not set in England, references here shall be made to the dated version.

The drama has several features that occur in later works: the hidden monster beneath the urbane exterior (Degenhart); the relative isolation of the location (a house cut off from the outside world); the use of courtroom style confrontations in which the truth is revealed (the dinner scene in Act II and the final scene), as conveyed by the title "Der Prozess"; and the inability to escape from one's past. This last motif is closely linked to the idea of flight in the drama. Yet, there is no escaping the fundamental weaknesses of the play, with its

1 Fritz Hochwälder, "Der Prozess. Schauspiel in 3 Akten", ts., undated, 66 pages, Hochwälder Nachlaß, Wiener Stadt- und Landesbibliothek, Wien; F. H., "Der Prozess", ts., 1938, 54 pages, Hochwälder Nachlaß, Wiener Stadt- und Landesbibliothek, Wien.

2 This is very noticeable in the last scene. In the English setting, Mary [corresponding to the character Marie in the German setting] seems far less in control, turning to drink to stiffen her resolve [61-62]. She also does not have the last word, that falling to her victim/persecutor Glenny [66].

3

In the opening scene of the third act, Ennest [Ludwig] refers to the strained atmosphere in the house over the last few days, when in fact the dinner table confrontation between Mary [Marie] and Glenny [Degenhart] took place just the previous afternoon [49]. In the next scene Mrs. Brown [Klement] reveals to Glenny that she knows John [Hans] is his lawyer when as far as she has been told they are simply friends [49], and therefore it is no longer clear why Glenny should presume it is Ernest who has betrayed him to Mary, when Mrs. Brown should have already aroused his suspicions.

${ }^{4}$ Bortenschlager, Der Dramatiker Fritz Hochwälder, 34-37.

5 Murphy, 45-50. 
contrived plot, illogical motivation and melodramatic devices, such as the locket containing poison through which the villain eventually meets his demise. In many respects the play might be seen as a portent for Hochwälder's later attempt at writing a thriller, Lazaretti oder Der Säbeltiger [see Chapter 7].

The behaviour of all three main characters, Ludwig, Marie and Degenhart is at times perplexing, although in the case of the latter this is explained by his apparently psychotic nature. However, they all share a desire to flee from that which they perceive to be a threat: Ludwig wishes to insulate himself from the negative aspects of the outside world, preferring to live in isolation surrounded by the beauty of his art collection; Marie has fled the man who she believed intended to destroy her ten years previously, and has since lived in fear that he will find her; while Degenhart, by nature the most antagonistic and confrontational of the three, is on the run from his most immediate past, having just been acquitted of a murder he did, in fact, commit.

Of all the characters, Ludwig is the most unconvincing, since neither his flight from the outside world nor his behaviour towards his guests is adequately explained. Nevertheless, his actions are essential to the plot. The haven he has created from the outside world seems to Marie an enchanting and safe refuge. He has quite consciously cut himself off from the world around him, as Frau Klement reveals:

[...] Zeitungen gibt es hier nicht. Herr Altmann liest keine. Er will vom Leben nichts wissen. Er lebt am ordentlichsten, sagt er, wenn er seine Sammlung in Ordnung bringt, die Gemälde restauriert, und schreibt. - Ja er sitzt oft tagelang beim Schreibtisch und schreibt. Aber nichts eigenes. Er schreibt, was ihm seine Sammlung erzählt.

$(\mathrm{DP}, 1)$

Such is his withdrawal that he has no visitors, except for occasional appearances by his brother, Hans, a lawyer in town. He has not even followed his brother's recent legal success, not because he does not wish him well, but because "das eine Sache [ist], die ihn aus seinen vier Wänden herausführt, und das mag er nicht" (DP, 2). He confirms this later himself: "[...] diese Mordgeschichte [interessierte mich] an und für sich nicht. Aber es ist mir natürlich nicht gleichgültig, ob mein Bruder beruflichen Erfolg hat oder nicht" (DP, 4). The world he has created seems perfectly insulated against the uglier side of life: "[...] hierher kommt nichts, was ekelhaft ist. Wird nicht eingelassen!" (DP, 5). Even when this confidence is shown to be misplaced, he does his best to avoid direct confrontation with the intrusions into his world ${ }^{6}$.

But, if Ludwig wishes to learn nothing of the outside world, he enjoys pursuing the truth when it comes to art. He likens his work as a restorer to a detective uncovering what is below the surface (DP, 6), and elaborates on this in the dinner scene:

Du darfst nur nicht glauben, dass Kunst und Sammlerleidenschaft nichts

6 In this regard, Ludwig has much in common with several of the residents of the Pension in "Casa Speranza". 
mit dem Leben zu tun haben. Denn man ist weder Geniesser noch Schöpfer, sondern steht zwischen diesen beiden als Forscher. Ja, ich behaupte sogar, jeder richtige Kunstsammler muss etwas von einem Kriminalisten in sich haben.

(DP, 33)

His work on the figure of Saint Sebastian, revealing the original work beneath the surface, can be seen as symbolic for the play as a whole ${ }^{7}$, representing the disparity between appearances and reality, between Schein and Sein. Indeed, the choice of Sebastian is significant, for according to legend, he was shot full of arrows for not being what he seemed, an ordinary soldier in the Roman army, but rather a secret Christian.

As events unfold, Ludwig seems most adept at uncovering the truth around him, and is soon fully aware of what has occurred in Degenhart's and Marie's past, and is in a position of knowing more than any of the other characters. Through questioning Hans he learns his guest's true identity is Friedrich Berger (DP, 8-9), a man recently acquitted of the brutal murder of a young woman (DP, 14), and then confirms for himself, and the audience, that this Degenhart is indeed Marie's former lover from whom she fled over twelve years earlier, when she became convinced that he wanted to destroy her (DP, 16-18). Yet despite knowing the danger facing Marie and realizing his guest is very probably a murderer, perplexingly Ludwig chooses to keep this information to himself, even though it would seem probable that by revealing his knowledge to either Marie or Hans the final confrontation might have been prevented, his apparent aim for much of the play.

This silence, essential as it is for the plot development, is partly explained, if not convincingly, by the story he tells at the dinner table in Act II, about an acquaintance who has discovered that he, rather than the state gallery, has an original masterpiece. Ludwig claims that were he the owner of the original he would not make his knowledge public: "Wozu? Er weiss doch, wo die Wahrheit steckt. Wozu es an die grosse Glocke hängen?" (DP, 35). However, regarding his knowledge of Degenhart and Marie, there is a very real reason why he might choose to reveal his knowledge, for it is a matter of life and death, and it is to this moral duty that Marie alludes when she manipulates the conversation [see below].

Indeed, both Marie and Degenhart reject Ludwig's caution and liken him to a snail, who withdraws into his shell, afraid of life (DP, 21, 28, 35). Degenhart in particular rejects this behaviour: "Ich mag das eben nicht. Ich verlange, dass man sich nach jeder Handlung oder - Tat, zum Kampf zu stellen hat" (DP, 2122).

Certainly, Ludwig's whole approach is to avoid discord and trouble, if at all possible. In the first act he attempts unsuccessfully to keep Marie and Degenhart apart, and thereafter tries to prevent open conflict breaking out between them. When Marie asks him whether he would be unhappy to see her leave with Degenhart he is evasive (DP, 27) and when he becomes alarmed at what

${ }^{7}$ Bortenschlager, Der Dramatiker Fritz Hochwälder, 36-37. 
Marie may have in mind he offers to help get rid of Degenhart and help him flee. He hopes to prevent things coming to a head by persuading Marie not to come down for the evening meal and to claim to have a headache (DP, 28). He later shows himself quite capable of lying in an attempt to keep the peace, when in response to Degenhart's interrogation he denies knowledge of both the locket (DP, 42) and of Degenhart's recent court appearance (DP, 44).

It is only when he becomes sure that Marie will not be dissuaded from her course of action, and after making her tell him what she has in mind (DP, 47), that he becomes her willing accomplice. He again lies to Degenhart, telling him that Marie is going into town with them, so that Degenhart will stay behind, thus allowing Marie the opportunity to be alone with her adversary (DP, 48). In doing so he manages to avoid involvement in any confrontation himself, by being absent from the house, yet is prepared to leave a woman, for whom he has admitted his affection (DP, 41), alone to face a murderer.

Marie's flight from the outside world is explained far more credibly in the play. Since fleeing Degenhart ten years before, she has lived a similar existence to her host's, choosing a safe life of obscurity as a piano teacher in a provincial Italian town (DP, 18). It is then not surprising that she finds Ludwig's home so reassuring and can claim "Ich fühle mich aber hier so sicher, Ludwig, wie ich mich während zehn Jahre in aller Heimlichkeit nicht sicher gefühlt habe" (DP, 8). From such apparent security she looks back on her earlier relationship and wonders whether it was herself who was really sick and if she had imagined it all. At the time, however, she was convinced that Degenhart was intent on destroying her in some monstrous psychotic game. As a last resort she even contemplated suicide as the ultimate escape, and still carries the fatal dose of poison in her locket. Since then, such is the similarity of her withdrawal from the world to that of Ludwig's, that she too does not read newspapers (DP, 2), and told Ludwig before coming to stay, that she did not wish to see anyone (DP, 8).

But unlike Ludwig, she is hiding from a world that contains a very real threat, which may appear again at any time to endanger her. This vulnerability is first revealed when she hears from Klement about Hans's success in the Berger trial, a case which has obvious similarities with her earlier relationship with Degenhart (DP, 2-4). The story clearly upsets her, and she cannot hide this from Ludwig, although she attempts to brush it off (DP, 5-6). Her composure is completely shattered when she hears Degenhart's name, and she initially wants to leave at once (DP, 8-9).

However, the pair do meet, and, at first, events would seem to confirm her earlier suspicion (DP, 16) that her fear of Degenhart was a figment of her imagination: "Ich war einfach krank damals. Ich dachte, hinter all Deiner $[\text { sic }]^{8}$ Willenskraft und Stärke steckte doch nur eine Bestie" (DP, 22).

Having spent many years in seclusion, running from her past, Marie's transformation to Degenhart's nemesis stretches credibility. When she learns through Klement that Degenhart is identical with the Berger of the murder case, she is much more able to control her emotions than she had been earlier,

${ }^{8}$ Hochwälder consistently uses capital letters for second person pronouns in the typescript. 
although she must still sit down. No longer does she become near hysterical and wish to run away, but rather maintains her composure and is able to reassure Klement that it is just coincidence that Berger looks so like Degenhart $(D P, 26)^{9}$. The dramatic change in her attitude becomes clear in the next scene through her ambiguous answer to Ludwig's question:

LUDWIG: Sind Sie zu der Erkenntnis gekommen, dass Sie sich damals geirrt haben, als Sie von Degenhart weggegangen sind?

MARIE: Meine Flucht, meinen Sie. Sagen Sie es nur ruhig. Ich bin jetzt $\mathrm{zu}$ der Erkenntnis gekommen, dass es nicht richtig war, zu fliehen. Flucht is keine Lösung.

(DP, 27)

This decision to run no longer but confront Degenhart becomes apparent at the dinner table. She appears wearing a fifteen-year-old dress, that she knows Degenhart will remember (DP, 31), and immediately signals by this that she no longer intends to let the past lie buried, despite her earlier agreement with Degenhart not to bring it up (DP, 21). Then, following Ludwig's story about the work of art, she recounts an apparently hypothetical story about a murder case: a man is found innocent of murdering a woman, only for another woman to surface later who was similarly persecuted but managed to escape (DP, 3637). Marie clearly implies that it is wrong for such matters to remain hidden. While Hans and Ludwig do not wish to be drawn into her "imagined" scenario, Degenhart, who, like Ludwig, cannot but help know what she is getting at, finally explodes in anger (DP, 37-38). There can be no doubt in his mind that she knows the truth and wishes to act upon it.

In Act III the roles between Marie and Degenhart have been completely reversed, with Marie now in pursuit of her former persecutor. She has left the locket where she knows Degenhart will find it, and in the opening scenes of the act her victim becomes increasingly nervous and panic-stricken as he begins to realize the threat she represents. She herself does not appear until the sixth scene, where she clearly lays down her challenge to Degenhart:

DEGENHART: [...] Hier ist Dein Medaillon! Ein ander mal streu Deinen Schmuck nicht vor meiner Tür aus! - Warum nimmst Du es nicht?

MARIE: Behalt es nur.

DEGENHART: Weshalb?

MARIE: Es ist nicht für mich bestimmt.

DEGENHART: Wie?

MARIE: Denk drüber nach. Du wirst Zeit genug dazu haben.

DEGENHART: Du sollst schweigen! [...] Ich werde allein wegfahren, hörst Du!

${ }^{9}$ The plot really struggles for plausibility here. Not only must Klement accept that Degenhart has a Doppelgänger, but that Hans knows both men. One would expect a natural reaction from her would be to tell Ludwig about the newspaper photograph and/or refuse to be in the same house as Degenhart/Berger, considering the monstrous nature of the crime Klement is convinced he committed. 
MARIE: Das wirst Du nicht tun.

DEGENHART: Wer sollte mich daran hindern?

MARIE: Ich.

She then arranges, with Ludwig's help, to be left alone in the house with Degenhart for the final confrontation, the "Prozess" of the title. Here, she openly reveals that she knows he is a murderer and that he cannot escape from her: "Warum sollte ich Dir künftig nicht überall hin folgen, überall Dich bewachen, Dir überall nachspüren... Die Verbindungen, die Du anknüpfst, beobachten - und die Menschen, zu denen Du gut bist, beschützen..." (DP, 51). She tells him she could live with him, with safeguards in place to prevent him from killing her ${ }^{10}$ but he would never have the security of knowing whether or when she will betray him (DP, 51). Marie knows that his nature will lead him to commit further brutalities and that she alone can stop him. His one way out is that which she had contemplated those years earlier:

[...] Du bist entdeckt! Ich kann Dich vernichten! [...] Ich will es doch gar nicht. Ich will bloss eines: Gehe den einzigen Ausweg, der Dir bleibt, lass Klugheit und Gefühl doch siegen über die Triebe, die Du im Leben nicht überwinden kannst! Befrei Dich und nimm das! (sie nimmt das Medaillon vom Tisch und streckt es ihm hin) Du sollst Dich auslöschen!

(DP, 52-53)

Rather incredibly, after only momentary hesitation, Degenhart agrees that this is the only way and takes the poison. However, the final irony is that despite engineering his death, Marie still loves him and dissolves into tears at the end (DP, 54).

Degenhart too, like Marie and Ludwig, is also a fugitive. Having won his court case he seeks refuge at Ludwig's to avoid the furore and angry crowd that had greeted the verdict, and must wait there until Hans can arrange for him to leave the country (DP, 10-11). Yet hiding is something he clearly finds difficult to do. He refuses to stay in his room when asked to do so in Act I (DP, 19) and so meets Marie. Then, when they are apparently back together, he cannot wait for them to be able to leave, finding the house, full as it is with relics of the past, oppressive and threatening (DP, 21-22). Cetainly, he would wish to put recent events behind him as soon as possible, and, as he insists to Hans, he does not want Marie to know of his court case (DP, 30).

However, if he has been reluctantly on the run from public attention in the first two acts, by the third his main concern is to flee from Marie, who, with her knowledge about him, is a real threat to him. His true nature begins to surface under pressure. He aggressively insists that Klement take the locket back to Marie (DP, 40) ${ }^{11}$, rudely challenges Ludwig about betraying him to

10 He cannot get rid of her now either since Ludwig and Hans, already suspicious, would immediately know what has happened.

11

He is even ruder in the other version [51-52]. 
Marie and knowing about the locket (DP, 41-45), and then is decidedly confrontational with Marie (DP, 45-46). As he becomes increasingly desperate he turns to Hans for help, and comes close to revealing the truth to his lawyer, who is, however, very anxious to avoid any unpalatable truths about his recent court triumph (DP, 49).

So Degenhart finds himself manoeuvred into being in the house alone with Marie. After initially resisting her arguments, he reasons that she is right and that the only escape is suicide (DP, 53). But this too is a form of Flucht, as it would have been for Marie ten years before, for he ultimately chooses to concede defeat rather than fighting her. Nevertheless, he is allowed some triumph in his demise, for despite all he has done, Marie still does love him. For all its flaws in logic and motivation, "Der Prozess" does demonstrate the thesis that running from danger and evil is in the end futile, since it cannot guarantee lasting security and is also morally wrong, since it exposes others to the same danger. Marie in the end must face up to Degenhart and destroy him, but it is too late for the woman he has murdered.

However, if flight is soundly rejected in "Der Prozess", after 1938 it must be accepted as a first line of defence, since after the Anschlu $\beta$, Hochwälder, like so many others, was forced into exile to save his life. Nevertheless, in the plays "Casa Speranza" and Der Flüchtling fleeing from danger is not an excuse to avoid battling evil, and both plays insist that the struggle for good must continue.

"Casa Speranza" portrays an exile in Switzerland which Hochwälder must have known all too well. "Casa Speranza" itself is a safe haven, a "House of Hope", away from the horrors of war and the Holocaust which are raging across Europe. In this relative security the residents of the Pension live in comfort, and some choose to ignore events outside, pursuing their own pleasures and petty squabbles: Siegfried Pasternak enjoys the company of Clelia Heidenreich, and dreams of some day being able to return to his life as a businessman; she hopes to become a famous author and is writing a glorifying account of the persecuted French Huguenots; and Zwonimir Petricewitsch contends with the long-running domestic battle with his wife Ljerka, and enjoys meaningless fights with Pasternak over chess games and cheating.

However, the death and destruction are never far away, even if some choose to ignore it. This is emphasized by the losses of the two youngest fugitives at "Casa Speranza", Dolores and Edi. Dolores is a refugee from the Spanish Civil War and has been orphaned by the bloodshed there (CS, 3, 24), while Edi, a refugee from Vienna, would rather not speculate about his parents' fate:

DOLORES: [...] Und wo sind denn Ihre Eltern, Edi?

EDI: Weiss nicht.

DOLORES: Wo waren sie denn zuletzt?

EDI: In Wien.

DOLORES: Und wieso sind sie denn nicht mehr in Wien?

EDI (nach einer Pause): Wissen S' was --- reden wir von was anderm [...] $(\mathrm{CS}, 24)^{12}$ 
The tragic racial policies destroying lives across Europe are ironically alluded to in the early conversation between Ulysse and the gendarme:

GENDARM: [...] Aber jetzt stehe ich vor der Rassenfrage.

ULYSSE: Wie?

GENDARM: Die Rassenfrage macht mir zu schaffen.

ULYSSE: Die Rassenfrage?

GENDARM: Ja. Welche Rasse ist die wertvollste - und welche gedeiht hier im Tessin am besten?

ULYSSE: Wie kommst du darauf?

GENDARM: Ich meine doch - Kaninchen. Was geht mich sonst die razza an. - Also ich habe mich belesen und da heisst es: alles kommt auf die Rasse an. Es gibt bessere Rassen und schlechtere. Und bisher dachte ich: Kanichen [sic] wäre Kaninchen.

ULYSSE: Für welche Rasse wirst du dich entscheiden?

GENDARM: [...] Ich werde mich für die beste Rasse entscheiden. Diese züchte ich ausschliesslich. Und die andern schlachte ich nach und nach.

ULYSSE: Das ist sehr modern [...]

The officer concerns himself not just with which rabbits may be allowed to thrive in the area, but in his official capacity, with which people may also be allowed to live there.

Not all the residents of "Casa Speranza" are oblivious to the outside world. The owner of the Pension, herself an exile of some years, demonstrates an empathy with those who are suffering a similar fate, and her sentiments are shared by her employee, Ulysse, and the young resident, Lilli Szekely. But, while they remain optimistic and do their best to be constructive in terrible times, Hermann Faden, Lilli's much older companion, is weighed down by the inhumanity taking place around them and despairs of humanity.

Again, as in the plays such as, "Der Prozess" and Die Herberge, and as will be seen in Der Flüchtling, the arrival of a stranger, the Jewish doctor, Frühberg, disrupts the comfortable order of things. He has avoided deportation from France by escaping from the last "Viehwaggon" (CS, 18), and as an illegal refugee his hopes for the future have been reduced to the most basic: "dass ich morgen noch lebe!" (CS, 45). Frühberg's presence not only exposes the pettiness and selfishness of the others, who dwell on their own problems and concerns while elsewhere in Europe people are fighting for their lives, but also challenges Faden's resignation. Indeed, by exposing the negative traits that lie just below the surface of civilised life, the play has much in common with Hôtel du Commerce, which also, in a much lighter manner, deals with fugitives.

However, in revealing the weaknesses of those around him, Frühberg also

12 Hochwälder's parents were transported to the death camps from Vienna after he himself had illegally escaped to Switzerland by swimming the Rhine. 
shows undesirable characteristics, demonstrating in person the validity of his view that persecution does little to better its victims. Although no psychopath like Degenhart in "Der Prozess", he nevertheless shows the same reluctance to come to terms with his position as a fugitive, showing an aggressive, combative attitude to those around him, despite the obvious danger this poses by drawing attention to himself and risking deportation. To make matters worse he has previously been in a fight in Switzerland which might damage his case for asylum with the authorities (CS, 19). Yet despite the pressing need to lie low, he does not seem able to avoid antagonizing those around him, even rudely insulting Edi, who, recognizing a fellow fugitive (CS, 53-54), attempts to offer sound advice. His behaviour does little to help his cause, and ultimately leads to his arrest.

Clelia Heidenreich's suspicions are immediately aroused as soon as he appears and hangs around looking for an opportunity to speak to Uexküll. She believes he is spying on them (CS, 15), and her hostility toward him is only increased by his subsequent behaviour. This "intellektuelle Gans" (CS, 4), aspires to be a novelist, and is writing about the Seventeenth Century persecution of the French Huguenots, the importance of which she explains to the newly arrived fugitive: "Von morgens bis abends schaffe ich an diesem Werk, das zu unserer Zeit sprechen soll [...] Das - ist der Roman unserer Zeit! In historischem Gewand natürlich [...]" $(\mathrm{CS}, 28)^{13}$. When asked his opinion of her work, Frühberg is blunt to the point of rudeness and rejects her heroic portrayal of her subjects:

Sie schreiben da einen Roman über die hugenottischen Flüchtlinge ----und stellen diese Expatriierten als lauter reine Engel hin- lauter Idealgestalten! --- Das ist falsch! [...] Richtig ist bloss, dass diese Flüchtlinge grausam verfolgt wurden. Aber es waren ebenso wenig - oder: ebenso viel --Lichtgestalten drunter ....- wie unter den Flüchtlingen unserer Zeit [...]

Her view of history, according to Frühberg, is completely false: the Huguenots were persecuted less for their faith than from economic jealousy, persecution did not make them better people, and they alienated their hosts in exile by their behaviour (CS, 30-31):

Statt lauter engelsgleiche verfolgte Seelen zu schildern, hätten Sie zeigen müssen: dass Not kein Gebot kennt! - So aber verfehlt Ihr Roman seinen Zweck, ja, er ist geradezu schädlich. Denn jeder weiss, dass Flüchtlinge keine Engel sind; und dass die Verfolgung den Charakter nicht bessert viel eher aus saturierten Bürgern heimatlose Lumpen macht -

(CS, 31)

While Frühberg might have told the truth, he has done it in a manner that he

13

There is some irony in the fact that Hochwälder himself had such success with works cloaked in historic garb, and later was to write a work concerning the persecuted Huguenots, the drama Donadieu. 
has not only made an enemy of Clelia but has drawn unfavourable attention from the others, who cannot but feel offended by his unflattering portrayal of refugees. Petricewitsch, a slavic political exile, certainly feels slighted, and physically and verbally attacks Frühberg, going into great detail about how he has been forced to flee his homeland for his idealistic defence of the rights of his compatriots (CS, 32-37). Pasternak is more honest in expressing his annoyance at Frühberg:

Was mengen Sie sich auch in Angelegenheiten, die Sie nichts angehn, Herr! - Ich weiss ja nicht, wer Sie sind --- aber merken Sie sich: wir sind hier froh, dass wir in Sicherheit Luft schnappen können; und wir wollen unsere Ruhe haben, unsern Seelenfrieden...

(CS, 37)

He shows no interest in events in the outside world and would be happy if the outside world showed no interest in him; far more important are his chess disputes with Petricewitsch (CS, 26-27), which Frühberg finds incredulous: "Keine andern Sorgen haben diese Leute!" (CS, 28).

But, far more important than these clashes with the residents of "Casa Speranza" is that between Fribherg and Faden, and through this between Frühberg and Lilli. Following Marie in "Der liebe Augustin", Lilli is another in the line of exemplary heroines, who show great compassion for their fellow human beings, and demonstrate how one should behave. It is she who introduces the expositional detail that refugees are fleeing the Nazis in France, and her concern is heightened by an awareness that, but for chance, she and Faden would have shared the fate of others less fortunate (CS, 9). Faden is extremely depressed about the world and seems to have given up hope, an attitude for which he is severely reprimanded by Lilli:

LILLI: [...] denke doch: das ist für viele von diesen Unseligen - die Deportation! Die Auslöschung.

FADEN (langsam): Die Auslöschung - ist das so schlimm?

LILLI (unwillig): Du versündigst dich! Der Elendeste lebt gern - das solltest du wissen.

FADEN: Der Elendeste...

LILLI: Und du -- hast am allerwenigsten Grund, den Kopf hängen zu lassen. Damit ich es dir einmal sage. [...] Ich kann diese Brille nicht leiden - durch die du die Welt ansiehst, Hermann. So muss man sie nicht ansehn - trotz allem: nein!

$(\mathrm{CS}, 10)$

Her insistence on a positive frame of mind is bolstered by the fact that she has just gained permission to work as a doctor at a clinic near Zurich (CS, 11), where she feels she can now really do some good.

But Faden remains unable to share her enthusiasm and his pessimism is reflected in his choice of reading matter: Schopenhauer. Frühberg discovers the book and cannot help but show his disgust when he reads the quotation "Der Tod ist der eigentliche inspirierende Genius oder der Musaget der Philosophie" (CS, 
22), and without realizing whose book it is makes his disdain clear to Faden (CS, 38), who takes offence. To make matters worse he then makes Lilli suspicious by claiming to be employed at the clinic where she is to work (CS, 37). This combined with her concern for Faden, who is obviously upset by Frühberg, leads to her agreeing with Clelia that Frühberg must leave.

The antagonism Frühberg generates comes to a head in the third act when he further challenges Faden's Weltanschauung, arguing that it is a duty to struggle against injustice and stupidity. Unwittingly he also suggests to Faden a course of action he will later take:

FRÜHBERG: Die Dummheit - die Schlechtigkeit - das Böse in der Welt - das alles ist doch kein Grund zur Resignation! Wer noch ein bisschen Leben im Leib hat, der stellt sich eben - zum Kampf!

FADEN: Und kämpft - gegen Windmühlen.

FRÜHBERG: Nein. Er kämpft überhaupt nicht - gegen. Er kämpft - für! [Hochwälder's emphasis]

FADEN: (spöttisch): Sie wollen wir [sic] doch nicht einreden, Herr Doktor - dass Sie [Hochwälder's emphasis] kämpfen.

FRÜHBERG: Natürlich kämpfe auch ich. Wie jeder lebendige Mensch.

FADEN: Und wofür kämpfen Sie - wenn ich fragen darf?

FRÜHBERG (nach einer Pause): Nun --- zum Beispiel dafür --- dass ich morgen noch lebe!

FADEN (verächtlich): Das ist eine Redensart.

FRÜHBERG: Glauben Sie mir: es ist keine Redensart. (laut): [sic] Uebrigens sollte jeder selbst wissen, wofür er auf der Welt ist. Wenn einer nicht mehr weiss, wofür er lebt - wenn einer so ganz ohne Hoffung [sic] ist -- ja: so einem wäre besser, er läge da draussen im See wenigstens ein Aas noch, vom dem die Fische fressen! $\quad(\mathrm{CS}, 45)^{14}$

This insistence that one must continue to struggle, despite the odds, is central to the play, which rejects both selfishness, resignation and apathy. However, Faden's cynicism would appear justified when Pasternak, Edi and Clelia reveal their self-centred hopes for the future (CS, 46-47). But Frühberg remains unshaken: "[...] lieber die dümmste Illusion als die vernünftigste Resignation!" (CS, 48). As the conversation develops Faden is forced to reveal the depth of his personal despair, which Frühberg angrily rejects as self-pity:

FRÜHBERG: ... worauf hoffen $\underline{\text { Sie? }}$ (Hochwälder's emphasis) [...]

FADEN: Auf - nichts.

FRÜHBERG: Wie?

FADEN: Ich hoffe - auf nichts... Ich hoffe nicht mehr-- es ist alles sinnlos. Ich sehe die Katastrophe - in jedem Fall. Was soll ich noch?

14 This philosophy is one that Hochwälder seemed to share for he ends his essay, "Kann die Freiheit uberleben?", which on the whole is rather pessimistic, with a quotation from Gottfried Keller: "Nur wer die Hoffnung gab verloren und böslich sie verloren gab, der wäre besser ungeboren: denn lebend wohnt er schon im Grab!", Im Wechsel der Zeit, 131. 
- In einem Rechtsanwaltsbüro sitzen, blödes Tagewerk tun - nach all dem Entsetzlichen, das wir alle erlebt haben? - Oder nach all dem jagen - was wir als Illusion erkennen mussten: Erfolg, Ehre, Reichtum, Glück, Familie... Damit in einigen Jahren das gleiche Verhängnis uns Narren wieder niederwirft? --- Nein: ich glaube an all das nicht mehr. Ich fürchte ein böses Ende nicht mehr und nicht weniger als ein sogenanntes gutes [...]

FRÜHBERG: [...] Herr -.-- wenn Sie wüssten --- wie kläglich Sie sind! In einer Zeit, wo Hundertausende um die blanke Minute kämpfen müssen - um das nackte Leben, wo Millionen schuldlos zugrunde gehn - Menschen, die etwas sind und noch was leisten könnten -..---da sitzen Sie hier, eingehüllt in geradezu paradiesisches Wohlleben -und was für Weisheiten verzapfen Sie? - "Ach - es ist alles so sinnlos --- all unser Streben: Eitelkeit..." --- Beinahe wünsch' ich Ihnen, Sie sollten einen Tag lang so gehetzt leben müssen, wie die meisten andern Menschen unseres Schlages - nur einen Tag lang! Dann würde Ihre Melancholie vergehn ---- Sie trauriger Ueberrest vom fin de siecle [sic]!

(CS, 48-49)

While there is much truth in what Frühberg says, and it merely echoes in much stronger terms that which Lilli had said to Faden earlier, he has gone too far this time. When Faden decides that "Casa Speranza" is not big enough for the two of them Frühberg finds himself confronted by a united front of Pension residents, who wish to see him leave, despite his belated attempt at an apology (CS, 50-51). He is left alone with his determination not to be driven away, well aware he has no where else to go (CS, 51).

However, despite his stubbornness, sometime later, after Frühberg has had the opportunity to add Edi to the list of those he has offended (CS, 52-54), Lilli nearly does make him leave. She knows that he is lying about the clinic and threatens to go to the police (CS, 55). She does this not out of personal malice but to protect Faden, who has been, literally as it eventuates, mortally offended: "Ich muss einen Menschen schützen - den Sie tödlich gekränkt haben - Sie ja Sie!" (CS, 54). However, when she learns that Frühberg is running for his life she is horrified, and compassionately tries to persuade Faden to forgive him. In doing so she is finally forced to reject fully Faden's outlook on life, which ultimately leaves him incapable of showing any sympathy toward another's suffering ${ }^{15}$ :

FADEN: Dieser Mann - steht für sich selber ein, glaube mir. Er gehört zu jenen Ellenbogen-Menschen, die uns immer geschadet haben.

LILLI: Gerade dem muss man helfen, der für sich selber einsteht!

FADEN: Du willst sich [sic] - für ihn einsetzen?

LILLI: Ja dasx [sic] will ich!

FADEN: Du - wendest dich ihm zu?

15 Here there is a strong similarity with Augustin, who in retreating into cynicism and black humour is no longer capable of human feelings. 
LILLI: Begreifst du das nicht?

FADEN: --- Unerträglich -- ist mir der Hochmut dieses Menschen! Was ist es denn für eine Kraft, mit der er aufprotzt? - Ein animalisches Anklammern an die Niedertracht des Lebens!

LILLI: Um Himmelswillen -- siehst du denn nicht, dass sein Leben auf dem Spiel steht! Hermann - jeden Augenblick muss er herunter kommen. Denn er will gehen - er [Hochwälder's emphasis]! Du bist in diesem Land überall sicher. Er aber hat in diesen Stunden nur dieses Haus! [...]

FADEN: Ich halte dich nicht. Stehe du zu diesem Mann. Ich - werde allein gehen.

LILLI: So bleibe doch - bleibe! -- Ist denn dein Stolz so gross, dass du dir das nicht vergeben könntest?

FADEN: (leise): Nein - gewiss nicht... Ich will es mir nicht vergeben, dass ich - so --- geworden bin --- dass ich nun nicht mehr sehe... Deshalb -- will ich auch gehen: allein! -- Ich werde gehen...

LILLI (umarmt ihn - küsst ihn leicht): Ich freue mich -- dass noch so viel Kraft in dir ist $[\ldots]$

(CS, 58-59)

Faden himself is forced to recognize what he has become, and although Lilli misunderstands his last words, it quickly becomes clear that, having lost all hope and now Lilli as well, he can no longer live with himself (CS, 60). His subsequent suicide and Frühberg's attempt to save him draw the attention of the local gendarme to the fugitive (CS, 62-64), leading to his arrest.

Even in this final act, despite the tragedy that has just taken place, there is no escaping the pettiness and selfishness of some of the characters at the Pension, confirming Frühberg's claim that exile is not an ennobling experience. The act begins with Ljerka Petricewitsch returning in tears to her husband, whom she had left, once again, at the start of the play. She is the picture of self-pity, concerned only with what she perceives to be her mistreatment at the hands of Petricewitsch, and shows no interest in what has taken place in her absence. For his part, he just seems to be interested in not drawing the attention of the police to themselves (CS, 65-66).

Those of a more altruistic nature, Lilli, Uexküll and Ulysse, almost divert the gendarme's attention away from Frühberg, but Clelia makes use of the opportunity to pay the fugitive back for his earlier lack of diplomacy and, in front of the officer, accuses him of causing Faden's death (CS, 69-70). With the policeman's suspicions once more aroused, the truth about Frühberg's illegal entry into Switzerland is revealed, and he is arrested.

Yet despite this the play ends on an optimistic note. The gendarme himself suggest things will not end badly: "Es wird nichts so heiss gegessen---" (CS, 73), and Frühberg now has the support of Uexküll and her friends, as well as Lilli. Lilli's quick recovery from the shock of Faden's death is somewhat unconvincing, but she justifies her support for the prisoner: "Die Lebenden stehn mir nah - nicht die Toten. Den Toten nützt keine Hilfe - den Lebenden 
muss man helfen..." (CS, 72).

Flight from the Nazis may be unavoidable if one is to live, but in a strong affirmation of Frühberg's earlier insistence that it is not enough merely to survive, but that one must also fight for what is right, both Uexküll and Ulysse vow that hope may never be allowed to be lost (CS, 73). This faith is justified in the final scene when Uexküll sanctions the blossoming relationship between the young couple, Dolores and Edi. Despite all they have gone through there is still a future to which to look forward.

The difficulty of reconciling the necessity of fleeing to survive with the duty to offer resistance to evil is also the central theme of Hochwälder's drama, Der Flüchtling. As in "Casa Speranza" the nature such resistance should take is not overtly addressed, prompting one critic to claim: "Die quälende, von Hochwälder [...] nicht angesprochene Frage aber bleibt die: Wehrt man sich, indem man flieht?"16 However, by having the fugitive intent on joining the resistance, the dramatist again insists, as in the earlier work, that one must continue to struggle against evil and injustice. Furthermore, at the end of the play the idea of flight is ambiguous and it is no longer clear if the title refers to the fugitive or his adversary, the border guard.

Hochwälder did not consider "Casa Speranza" anything more than a "Zwischenarbeit", and the play was never published, and he had a scarcely greater opinion of the later drama, Der Fliichtling. He expressed surprise at the success of the play, believing it to be built on very shaky foundations, and claimed he had tried to withdraw it from the public domain on several occasions ${ }^{17}$. Popular though Der Flüchtling might have been, this was not the case in Hochwälder's homeland of Austria, where it was ignored in the immediate post-war period and had still not premièred by $1976^{18}$. Perhaps its attack on Mitläufertum was a little too close to home for an Austrian political system keen to rebuild and put the past behind it ${ }^{19}$.

Hochwälder was never very specific about his particular reasons for not rating this drama highly, but James Schmitt suggests it could have had something to do with his indebtedness to another great dramatist: " $[. .$.$] perhaps he was afraid$ that its inspiration by the great dramatist Georg Kaiser would overshadow his own originality and audiences would acknowledge the stimulus (Kaiser) more than the response (Hochwälder)" 20 .

Certainly, as Hochwälder acknowledges in the full title of the play, the original idea was Kaiser's, who initially intended to write the play himself ${ }^{21}$,

16 Sigrid Petersen, "Grenzer und Flüchtling", Die Welt [Hamburg], 20. Nov. 1980. Cf. Ulrich Herzog, "Dem Unrecht Widerstand leisten", Fränkisches Volksblatt [Würzburg], 8. Feb. 1980.

17 Hochwälder, Im Wechsel der Zeit, 84-85.

18 Gotthard Böhm, 536. Productions were, however, staged in Austria in May 1981 and September 1985.

19 Friedbert Aspetsberger, "Versuchte Korrekturen. Ideologie und Politik im Drama um 1945", Literatur der Nachkriegszeit und der 50er Jahre im Österreich, Hrsg. Friedbert Aspetsberger, Norbert Frei, Hubert Lengauer (Wien: Österr. Bundesverlag, 1984), 247.

20 Schmitt, "The Theme of Responsibility [...]", 63. 
before encouraging Hochwälder to take up the work. Kaiser was an important influence on Hochwälder as his career as a dramatist was just beginning, and he described Kaiser as a "ein[en] väterliche[n] Freund"22. Julius Marx, a close friend of Kaiser's in exile went so far as to liken the relationship between the two to that between Socrates and Plato ${ }^{23}$. The influence of the renowned Expressionist dramatist can at times be detected in the drama, most noticeably through the designation of the characters as types, "Frau, Flüchtling, Grenzwächter" 24 , and the occasional emotive declaration such as that of the fugitive when leaving the woman for the first time: "Ein Mensch war Ihnen nah! Ein Mensch! Vergessen Sie das nicht!" (III, 75). However, it would be wrong to over-emphasize the influence of Kaiser on the play, for its subject matter has much in common with "Casa Speranza", and its rejection of simply following orders as a defence links it thematically to the later play Der öffentliche Ankläger $^{25}$.

Donald Daviau's explanation of Hochwälder's dissatisfaction with the play is even more debatable than Schmitt's :

[...] the central idea is troublesome, for it is not so much an anti-fascist play as it is a portrayal of a corruptible human being who sought only his own advantage at the expense of others. All Jesuit priests who truly believe in their calling would have had to act exactly like the Father Provincial, but not all border guards are corrupt or corruptible and thus would not face the same situation as Hochwälder's character. The play would have been stronger if the guard had been the good man he claimed to be, for then Hochwälder would have confronted the real dilemma of choosing between conscience and duty. As it is he begged the serious problem and contributed only to publicizing the question, not presenting the answer. Recognition of this deficiency is most probably why Hochwälder did not rank Der Flüchtling among his best works ${ }^{26}$.

Daviau's questionable interpretation of the central character of Das heilige Experiment will be returned to later, but his concept of a "good" border guard carrying out his duty under a fascist regime is a difficult one to imagine, and would seem to require a tacit acceptance of the defence of following orders. The border guard is clearly representative of the petty officials who are so necessary to keep the wheels of any totalitarian regime running, and can be seen as a

21 Cf. Georg Kaiser, Briefe, Hrsg. Gesa M. Valk, (Frankfurt/M: Ullstein, 1980), 888, 917, $937,940,942,959,962,1000,1005,1120,1127$.

22 Hochwälder, Im Wechsel der Zeit, 30.

23 Julius Marx, Georg Kaiser, ich und die anderen (Gütersloh: C. Bertelsmann, 1970), 146.

24 Hochwälder also revealed in conversation to Eileen Murphy [164] that he was influenced by Karl Schönherr's play, Der Weibsteufel (1914), and the designation of the characters as types as well as the setting are very similar.

25 See Chapter 3.

26 Daviau, "Fritz Hochwälder", 247-248. 
forerunner of his more illustrious fellow traveller, Fouquier-Tinville, in the drama, Der öffentliche Ankläger. It is the unacceptableness of such behaviour which is at the heart of the play.

If one is to hazard a guess at Hochwälder's dissatisfaction with the play, it may be that he felt unhappy with the somewhat black and white portrayal of events and the issues of right and wrong in the play, with its tendency toward melodrama, and with the rather didactic exchanges between the fugitive and the guard, all of which runs counter to the usual subtlety with which Hochwälder explores his moral dilemmas. This aside, there can be no denying the fact that the play is capable of producing powerful drama, which has undoubtedly contributed to its success.

As in "Casa Speranza" a fugitive arrives unexpectedly and destroys the sheltered, comfortable lives of the other characters. His desperate plight awakens the woman's conscience and hitherto untested altruism and forces her husband, the border guard, to confront his own behaviour and see himself for what he really is. While she is prepared to risk everything to help him, her husband's only concern until the end is to protect himself.

However, like Frühberg, the Flïchtling is no saint, and it is only through his own predicament and the subsequent contact with the woman, that he is forced to think of others. In the first act, he candidly admits that the behaviour of those now persecuted was, before they themselves became victims, no different from that of the unaffected:

Zuerst haben sie die Ausländer geholt. Da hat man gesagt: Was gehen uns die Fremden an? Weshalb sind sie gekommen, wären sie doch daheim geblieben. Recht geschieht ihnen! - Als dann die ersten von den Unsrigen geholt worden sind, haben die Leute nicht mehr so geredet. Als man den Fremden eine Grube gegraben hat, sind sie daneben gestanden und haben zugeschaut, und manche haben sich die Hände gerieben... Die verdammten Ausländer, nicht wahr? - Ein paar Wochen später hat der Teufel die Zuschauer beim Kragen genommen. War das eine Überraschung! Wer hätte das gedacht! Plötzlich ist den Leuten deutlich geworden, was gespielt wird $[\ldots]$

It is only when he was to be transported to the labour camps that he fully comprehended what was at stake (III, 73). In this respect, his earlier behaviour was not dissimilar to the woman's, who only has her eyes opened to what is happening around her when the fugitive arrives.

Until his contact with the Frau, he has thought only of himself, refusing to allow himself to be treated like an animal (III, 74), but when he overhears policemen talking of the punishment awaiting those who helped him, he returns to the woman: "Bisher hab ich nur an mich gedacht. Ich muß hinauf in die Berge! Mich dürfen sie nicht fangen! [...] Jetzt sind Sie [die Frau] in Gefahr!" (III, 87). Previously, love had only meant physical attraction, but since experiencing her kindness he now believes he understands its deeper meaning (III, 89). But his consideration for others extends beyond her, and 
when she urges him to get across the border to exile in a neutral country, rather than joining the resistance, he questions the morality of it:

Wenn ich drüben bin geschieht mir nichts. Für mich ist alles zu Ende. Was den andern geschieht, kann mir gleichgültig sein. Ich bin gerettet! Die zurückgeblieben sind, sollen sehn, wie sie mit denen von der Kaserne zurechtkommen. Mich geht das nichts mehr an. Ich arbeite tagsüber auf dem Feld oder wo man mich sonst einsetzt, und abends streck ich mich auf dem Strohsack in der Baracke. Ich bekomm zu essen, vielleicht auch Zigaretten, und warte geduldig, bis alles vorüber ist. Wie diese Teufel Tag und Nacht hier hausen, wie man junge Leute zusammentreibt und deportiert, das stört mich nicht! Es ist nicht meine Haut, die geschunden wird. Ich lache. Ich hab es besser getroffen. Ich war nicht so dumm wie die in den Bergen, ich hab mich rechtzeitig gedrückt. Das ist das Klügste, was ein Mensch in so einer Lage tun kann, nicht wahr?

(III, 92)

To behave in such a manner would be to act as several residents of "Casa Speranza" do, and both the fugitive and the woman reject such behaviour as wrong (III, 93): it is not enough simply to survive in the face of evil, it must be actively struggled against. The fugitive may be running, but he is running to join others who will collectively fight the dictatorship, and it is this assertion that belies Petersen's criticism [see above] that the play begs the question of whether flight is a genuine form of self-protection.

The fugitive's commitment to the woman who has saved him remains consistent for the rest of the play. It is for this reason that he is prepared to hand himself over to the Grenzwächter (III, 109), and why he again returns when he sees police coming to the house after discovering who has helped him (III, 119). His recognition of a decent fellow human is visually emphasized by shaking hands (III, 75, 93), and his emphasis on the importance of their encounter: "Ein Mensch war Ihnen nah! Ein Mensch!" (III, 75). It is a gesture that he later refuses the border guard: "Ein Unmensch sind Sie" (III, 111).

The arrival of the Fliichtling completely destroys the woman's perception of her world. Her hitherto sheltered existence has been turned upside down, as is immediately clear from the opening stage instructions, which show the destruction caused by a police search of the house (III, 67). She reveals that she previously did not concern herself with matters outside her own enclosed domestic world, which is clearly how her husband would wish it:

Sie müssen mir nichts sagen. Ich kümmere mich sonst nicht drum. Was hätte man für Sorgen, wennn [sic] man sich um alles kümmern wollte.[...] Warum soll ich mich drum kümmern? Das geht eine Frau nichts an, das sollen die Männer untereinander ausmachen [...]

(III, 71)

But her curiosity leads her to ask why the stranger is on the run, and when he tells her she is forced to recognize the injustice he is suffering (III, 75). This 
new knowledge compels her to reappraise her relationship with her husband, and during the play she is forced to reject the man with whom she has made her life. At first, she is staunchly loyal to him, and when the fugitive first returns to save her from recriminations she tells him she has nothing to fear from the Grenzwächter (III, 89). Later she defends what her husband would have done, had he been there: "Er hat heut Nachtdienst gehabt. Das war Ihr Glück. Sonst wären Sie längst in den Händen der Leute, die Sie verfolgt haben. Wär mein Mann daheim gewesen, er hätte Sie ausgeliefert, ohne Erbarmen. Es ist sein Beruf. Er kann nichts dafür" (III, 91).

However, when her husband returns, his behaviour quickly alienates the woman: firstly she learns of the book in which he has recorded the suspicious activities of those in the village, with the aim of using it against them if he has to (III, 96); then he tells how the woman who makes their bread has been arrested (III, 98-99); and finally when he discovers that the fugitive is hiding in their bedroom he plans to shoot him in the back to protect himself and his wife (III, 105). Having already pushed her husband away in revulsion (III, 99), the woman now locks herself in the room with the refugee (III, 106).

Yet notwithstanding all that has happened, she still refuses to desert her husband, despite every effort by the fugitive to persuade her to flee with him (III, 108). It is only when she is awakened by shots and presumes that her husband has killed the fugitive, that she completely rejects the Grenzwächter. She now prepares to leave, recognizing that she can no longer stay with a man she knows is capable of murder:

Wenn du deinen schlimmsten Feind umbringen willst, dann nimm das Gewehr und schieß mich nieder. Denn das schwör ich: wenn ich am Leben bleibe, dann werde ich nicht ruhn und rasten, eh du nicht deinen Lohn bekommen hast für alles, was du getan hast und tun wolltest!

(III, 118)

Even the return of the fugitive is not enough to save their shattered relationship (III, 119).

Of the three characters the most interesting is the Grenzwächter, whose position as an opportunistic Mitläufer is ruthlessly exposed during the play. However, not until the end of the play is he prepared to recognize this fact and indeed claims to have no sympathy for the political order, but rather is grateful to be in a position to protect himself from it: "Was sind das für Zeiten, mein Gott! Wie froh bin ich, daß ich dich [die Frau] hab und mein Haus und meinen Dienst, in dem ich sicher bin vor den andern, die jetzt das große Wort führen" (III, 79).

He has created for himself a seemingly secure domestic world, epitomised for him in the figure of his wife, who waits to answer his call as he returns home from work:

Es ist für mich der schönste Augenblick: Ich komm langsam über den Hügel, das Haus liegt in der Morgensonne, vor der Tür steht mein Weib und antwortet auf meinen Ruf. Wenn ich den Ruf hör und dich seh, vergeß 
Again, the similarities with the lives of characters in "Casa Speranza" are obvious, for like them he has his paradise and deliberately chooses to ignore the world outside.

Even more revealing is the passage where he recognizes how meaningless his existence would be without his wife: "Wer mir mein Weib nimmt, der nimmt dem Uhrwerk in mir das Gewicht, der sichere Gang ist beim Teufel, was bleibt, ist nichts als ein leeres Gehäuse, keinen Schuß Pulver wert!" (III, 103). As so often in Hochwälder's dramas, this is a hint of things to come, for having lost his wife at the end of the play, the border guard will sacrifice his life (III, 120). Before this, however, he justifies behaviour, born purely from self-interest, as being motivated from the best interests of his spouse (III, 94; 105-106).

The stance of the border guard is ironically summed up by the fugitive:

Ein braver Mensch, der keiner Fliege was zuleid tut! Abends gießt er die Blumen vorm Haus, füttert die Kaninchen und dankt Gott, daß er in Frieden lebt. Daß ein Sturm durchs Land fährt, der alles umschmeißt und verwüstet, das kümmert ihn nicht, er steht unter seinem sichern Dach und denkt: Krepiert, ihr da draußen!

(III, 111)

The guard's sense of security is a false one, but just like the Flüchtling, who paid little heed to the warning sign of the plight of foreigners when they fell victim to persecution, he is initially unaware just how precarious his position is. So he initially shrugs off the damage to which he comes home in the first act, blaming the broken crockery on the wind and an unstable cupboard (III, 78 ), unlikely though this might seem.

However, it does not take much to shake his complacency, and by Act II, even before he learns the full truth about the fugitive, he has become uncertain and worried. His wife's desperate efforts to protect the fugitive by pretending he is her husband in bed with her has led to the Grenzwächter being reported for shirking duty (III, 94). Not knowing the full story he sees himself as the victim of a conspiracy and now sees the damage done to their garden as a warning (III, 93). Under this perceived threat his darker side comes to the fore and reveals the full significance of his words: "Solange man mich in Ruhe läßt, bin ich der beste Mensch, den man wünschen kann" (III, 96). Once more, the fugitive ably describes his adversary's behaviour: "Weh dem, der es wagt, seine heilige Ruhe zu stören! Da wird er zur Bestie, die nicht fragt, wer Schuld hat. Mit einem Schlag verwandelt sich der gutmütige Mann in einen Teufel [...]" (III, 111). 
In defending himself against attack, the border guard reveals a much greater understanding of the system of oppression of which he is a part, than his protestations of just doing his job would allow: he is all too aware what the arrest of their neighbour means, although, as far as he is concerned, that "[...] kann uns gleichgültig sein..." (III, 99); he is au fait with brutal interrogation methods (III, 104); and must shamefully concede he knows all about roughing up prisoners (III, 110). He may just do his job, but clearly his conscience is scarcely troubled by what he witnesses.

The most damning evidence against him is the list he has collated of possible rebel sympathisers (III, 96). Here, he is going far beyond his stated duties and the virtues he espouses of minding one's own business and doing what one is told. The Flüchtling again explains such behaviour:

Was ringsum geschieht, daß die Welt angezündet wird von Verbrechern, das kümmert ihn nicht. Daß man freie Menschen zusammentreibt und zur Sklavenarbeit verschleppt, geht ihn nichts an! Er dient bloß. Wem er dient, das will er nicht wissen und wer es ihm ins Gesicht sagt, der ist sein Feind. Denn würd er drauf hören, dann könnte es sich im Handumdrehen herausstellen, daß er ein Handlanger von Verbrechern ist und also nicht um ein Haar besser als seine Herren. Wie es Verbrechern ergeht, weiß er. Und trotzdem will er nichts anderes, als in Frieden leben.

(III, 111-112)

Therefore, the fugitive refuses to give the border guard his hand, recognizing in him the obedient official so necessary for any tyranny to succeed (III, 111).

Yet despite the accusations of the fugitive, which hammer home the guilt of the Grenzwächter, and despite recognizing the truth in what is said, the border guard still sees himself as a decent man trying to survive in difficult times:

Es ist wahr! Dran hab ich nicht gedacht! Aber... (er nähert sich dem Flüchtling) die ganze Welt hat es doch gesagt, Leute, die klüger sind als Sie [der Flüchtling] und ich, in allen Zeitungen ist es gestanden: Wir sind erledigt. Aus und erledigt! Und daß sich jeder, der nichts anderes als seine Ruhe haben will, gut stellen soll mit denen, die jetzt das große Wort führen!

(III, 112)

The fugitive's certainty that the regime will eventually be toppled now poses another danger for the border guard's peaceful existence: should this be correct the Grenzwächter might be held accountable for his service under the oppressors (III, 113). For this reason, once again borne of self-interest, he decides to help the refugee escape, and is even willing to make a "sacrifice" himself by admitting shirking duty and being in bed with his wife (III, 114). However, when the fugitive returns for a last time to encourage both the guard and his wife to flee, he concedes that right up until the last minute he had contemplated committing murder: 
Als ich Sie [den Flüchtling] hinausgeschickt hab, vor einer Viertelstunde da hab ich es mir noch einmal überlegt, ob es besser ist für meine Frau und mich: Sie laufen zu lassen, wie ich es Ihnen versprochen hab -oder Sie hinterrücks niederzuschießen... Und weil ich zum Schluß gekommen bin, $\mathrm{daB}$ es nützlicher ist, mein Versprechen zu halten, deshalb stehn Sie noch da und atmen und leben...

(III, 119)

Yet, his very efforts to preserve what is his in the end destroy him, as they do Fouquier-Tinville. His callous disregard for anyone else has been exposed to his wife, and when she realizes that he would kill another human in cold blood just to protect himself, she declares herself his enemy (III, 118). In his speech to her before she leaves with the fugitive, he finally recognizes the folly of his actions, which in the end have destroyed that which he wished to protect:

Ich hab alles falsch gemacht. Falsch - von Anfang an falsch. An mich hab ich gedacht, immer nur an mich. Was die andern durchmachen, was ringsum geschieht, das hat mich kalt gelassen. Meine Frau, mein Haus, mein Dienst, alles was mir gehört, das war mir auch alles. Ruhig hab ich zugesehn, wie den andern eine Grube gegraben wird und hab mir dabei gedacht: Was geht es mich an, sie ist nicht für mich bestimmt. -Jetzt seh ich: Nicht nur der, der eine Grube aushebt - auch der, der gleichgültig danebensteht und nichts dagegen tut, daß sie gegraben wird- auch der muß hinein, am Ende. - Davon wollt ich nichts wissen. Nichts hören und nichts sehen. Ja - ich - ich war in Wirklichkeit der Flüchtling! Ich! Ich! - Wer solang auf der Flucht war, der muß einmal stehen bleiben. Es kommt ein Augenblick, da erkennt er, daß kein Weg weiter führt. - Ich bleibe stehn. - Hier.

(III, 119-120)

This important passage makes clear that the border guard is as much a fugitive as the Flüchtling, and deliberately evokes the imagery of the fugitive's earlier description of indifference to the mistreatment of foreigners (III, 72). Clearly, it is not enough merely to flee from danger, indeed, this may in the end be self-defeating, rather one must also actively struggle against it. This is further emphasized by the fugitive's parting words, which strongly echo the sentiments expressed by Frühberg in "Casa Speranza": "Es muß jeder wissen, warum er weiter leben will [...]" (III, 120) ${ }^{27}$.

The play certainly has its weaknesses, at times hammering home its points in a none too subtle manner ${ }^{28}$, and the melodramatic death of the border guard has, in particular, drawn criticism ${ }^{29}$. The finale which leaves no loose endings

27 Compare this to Frühberg's sentiments in "Casa Speranza": "[...] jeder [sollte] selbst wissen, wofür er auf der Welt ist. Wenn einer nicht mehr weiss, wofür er lebt [...]" (CS, 45).

28 In particular the exchange between fugitive and guard in Act II seems contrived and overly didactic.

29 Aspetsberger, 247; Hans Heinz Hahnl, "Flüchtling und Mitläufer", Arbeiter Zeitung [Wien], 8. Mai 1981, 15. 
is certainly dramatic, but in its defence, it has already been established that the guard's entire existence, toward the protection of which he has devoted himself entirely, has been completely destroyed when he realizes he has lost his wife. Like Faden in "Casa Speranza" he has little to which to look forward.

Yet for all the didacticism of the drama, Donald G. Daviau can still make the following assertion:

Hochwälder seems to be saying that in a time of moral crisis one must not remain neutral, a criticism possibly leveled against Switzerland ${ }^{30}$. The play's problem is a serious one - caught up in tyranny, at what point does an individual know when he should defy orders or in effect become a traitor to his country to avoid crimes against humanity $[\ldots]^{3 !}$.

There is no more salutary a warning of the dangers of misguided nationalism in European history than the period of the Third Reich, to which the play clearly refers, and it is surprising that Daviau should see a dilemma in the drama between patriotic duty and the need to resist crimes against humanity. In fact, nowhere does the Grenzwächter show nationalistic fervour and he is clearly motivated by self-interest rather than by any notion of duty to his country. Indeed, the only character to mention feelings for his Vaterland is the fugitive himself, who only really learned the significance of the concept of a homeland when he travelled across his country in the confines of a cattle waggon (III, 89).

Nevertheless, Ulrich Herzog also shows some sympathy for the border guard's position, wondering: "[...] Welche Möglichkeiten zu wirksamem und sinnvollem Widerstand gibt es für den 'kleinen Mann'? Und wie verhält sich diese Widerstandspflicht zu dem 'Streben nach Glück', das doch ein erklärtes Menschenrecht ist?"32 Yet, as the border guard recognizes at the end, and as is emphasized in both "Der Prozess" and "Casa Speranza" the solution cannot be found in closing one's eyes to reality in the hope that it may go away, or at least by-pass oneself. Not only is it morally reprehensible to attain happiness at the expense of others, but such a "Streben nach Glück" is also misguided, since running away from evil, both figuratively, like the border guard, or literally, like Marie, cannot guarantee security from it. The tentative optimism in all three plays is that evil can and will ultimately be defeated by resistance,

30 In fact a closer reading of the play would discount any criticism of the Swiss. When the fugitive first returns to the house the woman suggests smuggling him across the border to a neutral country where he will be interned, but safe (III, 92). Indeed, Swiss neutrality provided the dramatist himself with safety from what would have been almost certain death. The proximity of a neutral country to the "Dreiländerecke" in the play suggests either Austria (since the fugitive is to be taken across a northern border as slave labour) or as has been suggested by one critic Northern Italy, where the German forces of occupation did employ forced labour [Herzog, "Dem Unrecht Widerstand leisten"].

31 Daviau, "Fritz Hochwälder", 247.

32 Herzog, "Dem Unrecht Widerstand leisten". 
and injustice will eventually catch up with its perpetrators ${ }^{33}$.

33 The theme of flight is treated in a much more light-hearted manner in Hochwälder's earlier verse play, "Eulenspiegels Erdreich". This short single act play, described by Bortenschlager (Der Dramatiker Fritz Hochwälder, 37) as a "Fastnachtspiel" may have been intended as a Hörspiel, such are the verbal descriptions of actions in it. In it Eulenspiegel returns to the land of his birth, tired of the life of a fugitive after a life in exile running to keep one step ahead of the noose. However, such is the reputation his exploits have earned that he faces the death penalty in his home land, for having so damaged its reputation. Eulenspiegel determines to stay and confront his would-be judge and to avoid the rope he plays one last prank on the Herzog, for having purchased a cart full of earth he is able to stand on his own independent ground, over which the duke has no authority. The joke succeeds and he is pardoned and left free to enjoy his freedom, no longer having to run. 